Open Access

\title{
Social exchange in collaborative innovation: maker or breaker
}

Malin M. Malmström ${ }^{*}$ and Jeaneth Johansson ${ }^{\dagger}$

\author{
* Correspondence: malin. \\ malmstrom@ltu.se \\ ${ }^{\dagger}$ Equal contributors \\ Luleå University of Technology, \\ 97187 Luleå, Sweden
}

\begin{abstract}
Collaborations in innovation work between competitors have become a common practice in the information and communication technology sector (ICT), and substantial investments are made in such collaborations. Significant rationales for these collaborations include the high expectations placed on rapid and front-edge technology development and business exploitation. However, there is often a failure to reach the expected outcomes of such collaborations. This may be explained not only by the challenges and obstacles in technology development but also by the social relations within the collaborations. The purpose of this study is to explore the role of social exchange in the outcomes of early-stage innovation collaborations. More specifically, we explore the social facilitators of exchange and how such facilitators may influence collaboration outcomes. Social exchange theory is used for this purpose. This longitudinal study is based on a 3-year collaboration project for innovation using qualitative methods (29 interviews, observations of 7 project meetings). Three phases of social exchange in the collaboration are empirically identified: the dating phase, brainstorming phase, and decision phase. Three social facilitators of social exchange within these phases are conceptualized: trust, commitment, and congruence. Further, direct contacts are conceptualized as a social accelerator fueling these social facilitators. This study advances understanding of social facilitators in social exchange and their significance with regard to success/ failure outcomes. Risks of lock-in situations in collaborations for innovation are outlined in a knowledge exchange paradox.
\end{abstract}

Keywords: Collaboration model, Innovation, Exchange, Social facilitators, Trust, Project failure

\section{Background}

Academic interest as well as practitioners and policymakers' interest has long been focused on innovation-related topics. This is not surprising, as innovations are engines allowing businesses to stay competitive and prosper in the marketplace (Amit and Schoemaker 1993; Rakhmatullin and Brennan 2014; Chronéer et al. 2015; Johansson and Malmström 2013). Successful innovations help develop successful organizations, and society as a whole benefits as new ventures emerge and grow (Osterwalder and Pigneur 2004; Chesbrough 2010). Today, interorganizational collaborations are considered to be an answer to a range of challenges that may hamper businesses from remaining competitive. Most collaborations with other organizations targeting innovation facilitate the exchange of information, knowledge, and experiences, accelerating learning and new ways of thinking and working in the

\section{Springer}

(c) 2016 Malmström and Johansson. Open Access This article is distributed under the terms of the Creative Commons Attribution 4.0 International License (http://creativecommons.org/licenses/by/4.0/), which permits unrestricted use, distribution, and reproduction in any medium, provided you give appropriate credit to the original author(s) and the source, provide a link to the Creative Commons license, and indicate if changes were made. 
organization (Malmström and Wincent 2012; Malmström et al. 2013) . Although it is commonly believed that increased levels of collaboration between organizations lead to better innovation outcomes (Rigby and Edler 2005), there is debate as to the effect of collaboration on innovation outcomes, with a broad range of views on what roles such collaborations have with regard to innovation outcomes and aligned competitiveness. In particular, recent interest has focused on the effects of collaboration for innovation on organizational performance. One question is whether investments in collaboration for innovation result in commercial innovations (Rakhmatullin and Brennan 2014). However, much of the extant literature shows inconsistent results. While collaborations for innovation are expected to bring advantages to collaborative partners, findings in prior studies have been mixed. On the other hand, individual organizations have little incentive to make heavy investments in early-stage innovations, when the risks of failure are high.

Studies have provided evidence that collaboration for innovation alone does not guarantee successful outcomes, and in some cases, it may produce even poorer outcomes (Miles et al. 1999; Nieto and Santamaría 2007). Even so, there is a lack of insight into why collaborations succeed or fail to reach the intended outcomes, and this study aims to address this shortcoming. For collaboration to occur, some form of social exchange is needed. Thus, we posit that social exchange is critical for collaboration outcomes concerning innovation. However, studies have largely overlooked the potential of social relations to explain the outcomes of collaborations for innovation. Therefore, the purpose of this study is to explore the role of social exchange in explaining the outcomes of an early-stage innovation collaboration. More specifically, we explore social facilitators for exchange and how such facilitators may influence the collaboration outcomes. Social exchange theory is used for this purpose. As such, this research contributes with a new conceptualization of social exchange by detailing the microfoundations of social exchange. We conceptualize social exchange elements in collaboration in innovation (four types of exchange capital and social exchange mechanisms, i.e., three social facilitators and an accelerator fueling the social facilitators) and thus add to the literature on collaboration in innovation. Although our work cannot be considered definitive, our most significant contribution is demonstrating how actual collaboration work may evolve as well as the role and nature of social exchange in collaboration-something that has, to the best of our knowledge, not previously been explored.

The paper is organized as follows. First, we report on a literature review and outline the theoretical basis of social exchange in collaboration and for collaboration outcomes. Next, we discuss our case and issues pertaining to our research methods and present our analytical procedures. We then outline the findings in three identified phases-the dating phase, brainstorming phase, and decision phase-and depict the essence of exchange in these phases. This study conceptualizes three specific social facilitators and their roles in cultivating social exchange of four types of capital (financial, human, social, and innovation capital) in the three identified phases of a collaboration innovation project and examines the accelerating effect of direct contact on the social facilitators. Finally, the paper concludes with a discussion of our findings along with implications, limitations, and directions for future research.

\section{Literature review and theoretical perspective}

Collaboration in innovation projects has become a common practice in the information and communication technology sector (ICT sector) (Emden et al. 2006), and substantial 
investments are made in such projects (Madill et al. 2007). Significant rationales for these innovation collaborations include the high expectations placed on rapid and front-edge technology development, better access to resources, and business exploitation (Goerzen 2007; Laperche and Liu 2013). In addition, organizations expect to achieve technology transfer for the development of new technologies and services, knowledge transfer for the acquisition of new competencies, and competitive advantages. Such achievements might otherwise not have been obtained (Knudsen 2007). A large body of literature has highlighted other benefits from collaboration for innovation, such as offering a mechanism to parry potential market failures ahead of market launch (Caloghirou et al. 2003; Hagedoorn et al. 2000; Vonortas 1997). The fundamental argument regarding the risk of market failure when making innovation investments illuminates the lack of incentive for individual organizations to solely undertake such investments. Another advantage of collaboration in innovation that has been pinpointed in the literature is better access to markets (Laperche and Liu 2013). It has been argued that innovation collaborations may enable organizations to share innovation costs and reduce uncertainty while providing opportunities to internalize new knowledge and achieve innovation synergies (Spivack 2013). Such aspects may be particularly important in earlystage innovation work, when risks and uncertainty are high and collaboration may enable organizations to spread these risks (Miles et al. 1999; Anderson 1990). In particular, studies emphasize the advantage for "resource poor" small- and medium-sized enterprises (SMEs) that gain access to other organizations' innovation capacity and paths to commercialization. Further, since the commercial success of innovations is often time lagged to when the financing for the innovation work is needed, participating in interorganizational collaborations may be beneficial (Malmström 2014). Such collaborations may be particularly beneficial to SMEs since traditional financiers are rarely willing to fund SMEs in their early innovation work as it may take several years before the innovations provide any return on the financiers' investments. Typically, it is not until a business can demonstrate a solid track record in sales and innovation development, show a prototype, or are about to commercialize a product that venture capitalists and other financiers are willing to invest (Johansson and Malmström 2013). However, it could be argued that when SMEs participate in innovation collaborations, they risk becoming dependent and thus jeopardize their ability to appropriate most—or all—of the returns from their investments (Miles et al. 1999).

While collaborations in innovation projects are expected to result in advantages to collaborative partners, findings in prior studies have been mixed. In fact, the degree of failure in the business models of innovative organizations as a result of collaborative innovation projects is high (Chesbrough and Rosenbloom 2002; Malmström et al. 2015). This high rate of failure is not only due to the challenges and obstacles in technology development but also to the social relations within the collaborations. Therefore, it is surprising that so few studies have explored the importance of social relations in collaborations intended to move early-stage technologies towards financially viable business offerings. In one such study, it was found that limitations in partners' abilities/ willingness to exchange information regarding their own high-tech offerings had negative effects on innovation outcomes in collaboration projects (Knudsen 2007). Similarly, negative effects of social relations in collaborations have been reported in terms of leakage of core competitive knowledge to collaborative partners (Emden et al. 2006). 
Social exchange theory has shown the potential to explain collaborations in innovation projects (Brass et al. 2004). According to the theory, an exchange requires a bidirectional exchange-something has to be given and something has to be returne$\mathrm{d}$-and over time, the exchange results in mutually rewarding transactions and interdependent relationships (Blau 1964; Cropanzano and Mitchell 2005). Social interactions are focused on discerning how actors' pasts and anticipated rewards mutually influence their choices, conduct, and social relations in a group (Blau 1964). The main idea of the theory is that social exchange is built on a cost-benefit perspective based on self-interest (Homans 1958). Actors only contribute resources when they perceive that their contributions will be reciprocated (Blau 1964), and as relationships evolve, the possibility for exchange emerges. Partners adapt to certain principles that form norms guiding the exchange; namely, the reciprocity and negotiation principles (Emerson 1976). The reciprocity principle is a standard for behaving in an exchange. When partners negotiate (e.g., to gain benefits such as financial exchange), they apply the negotiation principle (Gouldner 1960; Cropanzano and Mitchell 2005). Social exchange is thus proposed to be central to the success or failure of collaboration projects.

\section{Method}

This embedded case study (Yin 2003; Eisenhardt 1989) is based on a 3-year collaboration project for innovation in the ICT sector. The project included 19 organizations in 7 European countries in a private public partnership (PPP), consisting of a range of organizations from research institutes $(N=2)$, universities $(N=2)$, organizations representing clusters of SMEs $(N=5)$, public companies $(N=4)$, and large international corporations $(N=6)$. The organizations were based in several countries: four in Germany, four in France, four in Greece, three in Finland, one in Ireland, one in Spain, one in Sweden, and one in Italy. Data were collected via 29 interviews with collaborative partners, totaling $30 \mathrm{~h}$, and in situ observations of 7 collaboration meetings, totaling 14 working days. Interviews were recorded and transcribed. In situ observations of collaboration meetings were recorded when allowed, and notes of discussions were taken during all observations.

As recommended in the methodological literature on qualitative research, we engaged in content analysis of the data collected to capture themes and the nature of exchange in collaboration in innovation as well as aligned mechanisms fostering exchange. An established three-step procedure was used to guide this work. First, content analyses of the collaboration contract, which included 176 pages and 70,839 words, was carried out using NVivo software (http://www.qsrinternational.com/product) to identify which kinds of exchanges were emphasized and negotiated when entering the collaboration projects. Second, we began to code the interview data and the observation data. In this coding process, we first identified three project phases: the dating, brainstorming, and decision phases. The dating phase lasted for roughly 1 year while the brainstorming phase extended for 1 year and 3 months. The decision phase lasted 9 months. Project meetings marked the change from one phase to another. The dating phase consisted mainly of discussions related to getting to know each other, identifying who could contribute and how, and exploring overall technology design and strategic choices. In the second phase, considerable attention was given to solving technology difficulties and presenting a viable solution along with preliminary discussions on how 
to design a sustainable business model for the innovation. The last transit to the decision phase revolved around taking a stance on the produced technology and business model alternatives.

In the subsequent coding of the phases, we identified the following when categorizing the themes of exchange: (1) social exchange elements, i.e., four types of exchange capital, financial capital, innovation capital, social capital, and human capital; and (2) social exchange mechanisms, including three social facilitators and one accelerator. We reached this result by engaging in a line-by-line examination of the transcribed text, which was guided by our conceptual basis for generating themes and relationships among the themes, as recommended by Strauss and Corbin (1990). We used a set of guiding questions when we scanned and searched for statements and expressions, such as: What type of exchange took place/did not take place? What were the main arguments for exchange or no exchange? What enabled/hindered the exchange? These questions helped us to balance between richness and direction (Miles and Huberman 1994). Triangulation using different data sources aimed to validate and crystallize the studied phenomena. Content analyses were carried out by the two researchers individually and compared for matching degree (over $95 \%$ matching). The findings were also validated through feedback from the organizations' representatives.

\section{Results}

\section{Collaboration exchange}

The aim of the collaboration innovation project and its aligned exploitation activities, as outlined in the collaboration agreement contract, was the creation of a selfsustained, economically viable, and legally formalized organization to provide an infrastructure for the commercialization of European testbed services through a collaboration model. We identify three main phases in the collaboration innovation project: the dating phase, brainstorming phase, and decision phase. Each phase is presented below, where we identify four types of exchange capital (financial, human, social, and innovation capital), exchange mechanisms in terms of three social facilitators (i.e., trust, commitment, and congruence), and one accelerator for exchange (direct contacts) as a way to strengthen the social facilitators.

\section{Dating phase}

\section{Collaboration agreement}

The collaboration agreement contract shows a negotiation emphasis on innovation capital while financial capital, human capital, and social capital are more overlooked and thus left to develop over time, following the reciprocity principle. A word frequency search illustrates the emphasis on innovation capital (Table 1). Accordingly, the most established exchange in the collaboration agreement contract was innovation capital, supported by the negotiation principle.

According to the collaboration agreement contract, the collaboration set out to build on four fundamental collaboration cornerstones in which the emphasis on innovation capital is evident: (1) openness, (2) excellence, (3) efficient management, and (4) governance, (see Appendix 1 for details). Regarding openness, the focus is on intellectual property rights (IPR), and thus innovation capital, and pinpoints the importance of 
Table 1 Emphasis of discourse in negotiated exchange

\begin{tabular}{lll}
\hline Exchange of capital & Words & Frequency \\
\hline Financial capital & Cost & 32 \\
& Finance & 24 \\
& Price & 5 \\
Sum & Revenue & 2 \\
Human capital & & 63 \\
& Knowledge & 62 \\
& Capability & 58 \\
Sum & Experience & 53 \\
Social capital & Competence & 6 \\
& & 179 \\
& Collaborate & 54 \\
Sum & Share & 22 \\
Innovation capital & Exchange & 20 \\
& Integrate & 11 \\
& & 107 \\
& Testbed & 515
\end{tabular}

possibilities for exchanging innovation capital. For instance, it is stated that important challenges regarding innovation capital are: "Intellectual Property Rights (IPR), how to exchange results and what may be shared, the standardization of interfaces, common procedures, and usage policies." Excellence refers to innovation excellence in the collaborative model, thus focusing on innovation capital. Efficient management refers to achieving cost efficiencies and improving the sustainability and quality of the collaboration, thus focusing on financial and innovation capital. Finally, governance refers to the exchange of innovation capital, emphasizing that legal frameworks should include definitions for confidentiality and trust as well as sanctions for conflicts and misuse of the innovation capital.

Innovation capital is highly present in the collaboration agreement contract, where emphasis is placed on technology. Aspects of technology are placed at the heart of the collaboration, and trust regarding innovation capital is emphasized. For instance, the contract states: "The proposed testing service infrastructure will have a major goal of building trust-enhancing capabilities." The negotiation principle is considered as a means for solving trust challenges of the innovation capital exchange through the establishment of rules and structures for contracts regarding confidentiality issues and IPR.

The environment for the collaboration between the partners and the attached industry cluster(s) is further outlined in the collaboration agreement contract, which "will be characterized by a close cooperation among the participating actors and with strong ties with the local business infrastructure and the local higher education and research establishments." An expression of how to build commitment among partners is stated in the first exploitation activity: "Building commitment among relevant stakeholders for their 
longer-term engagement in testbed collaboration through bi- and multilateral discussions and memorandums of understanding." Further, negotiation of partners' commitment is also evident with regard to solving IPR issues: "In order to ensure an effective exploitation of the project results, the consortium partners will make an effort to solve any potential intellectual property issues that might arise."

The collaboration agreement contract shows partners' congruence for actions (if required) for dealing with pre-identified collaboration risks, which may be categorized as belonging to the four types of capital. These risks are: (1) financial capital risks, including the risk that no major customers will use the results, the market environment or the end-user views may change and make the results obsolete, and a competing solution will emerge and make the results less valuable; (2) human capital risks, including the risk that a key person with a specific type of expertise leaves the project; (3) social capital risks, including the risk that a partner is underperforming, a key partner is leaving the project, or the partners cannot agree due to conflicting interests; and (4) innovative capital risks, including the risk that key technologies or components are not available at the expected time and that key milestones or critical deliverables are delayed.

\section{Expressions of collaboration exchange}

At the initial meetings, partners showed enthusiasm and expressed excitement. One partner offered a typical expression of trust and commitment for reaching the collaboration goals: "I'm excited about this project because we're going a step further than most projects..." Partners expressed a congruent view and optimistic expectations of reaching a collaborative business model for financial, human, social, and technology exchange. For instance, one partner said, "competition isn't an issue as it would be for others. I think the businessmen in our cluster would actually be very happy to work with a lot of the partners..."

In the initial project meetings, it became clear that there was generally a neutral attitude among partners regarding how to deal with the financial capital. They spoke of pricing, finance, and doing business within the collaboration model, assuming that the innovation would automatically generate financial capital. This shows the high level of congruence among partners regarding financial capital. For instance, one partner stated, "I think anybody should be interested to pay for this kind of service." They avoided detailed discussions on who, where, how, and when to exchange, indicating a moderate commitment and level of trust regarding financial capital. Human capital was scarcely discussed, and when it was, the focus was on the exchange of technology competence. For example, when one partner stated, "Of course there are risks related to the competencies of the people whether companies send the right people or if, the level of engagement is low or so," another responded, "I have trust in the people who are doing the technology development." This demonstrates that trust levels were high that partners had the appropriate competences to succeed, but there were some doubts as to whether partners would actually provide that competence, indicating moderate commitment and congruence regarding human capital.

Much focus in the discussions was placed on the social capital. Long-term social exchange related to technology was emphasized while social relations related to business were neglected. Overall, high levels of trust, commitment, and congruence among partners were expressed. One partner displayed a typical expression of trust and 
commitment: "A lot of trust is needed... This is based on the professional social networks that exist from previous relationships, from previous projects and generally the engagement of all partners in different forms of collaboration over the years." Typical expressions of congruence by partners included: "we have very good collaboration with project partners in the past and we still have that", "we know them and we have worked with them before," and "I'm here for collaborating in a specific technical area, it's much easier for me to do with somebody that I know." A few partners discussed social exchange differently, emphasizing the need for developing trust to accomplish social exchange activities as well as efforts to build trust and commitment. One partner stated, "you have to build trust over and over again, with different people. Sometimes in big companies if you loose one contact it takes a year or two to find another who is in charge of that business area. That's hard work."

Partners emphasized innovation capital in an optimistic tone, where collaborations were expected to provide access to others' resources, demonstrating the partners' high commitment and congruence. High congruence was also evident in the shared view of striving to create a technology infrastructure that would be beneficial to all collaborating partners for a long period of time. They expressed a high level of trust that their partners would contribute in the exchange, and they perceived the risks related to collaboration in technology to be relatively low. One partner reasoned that the project would help technologies mature and allow customers to learn about them, speculating that in maybe 2 or 3 years, the innovation of new services could be offered to the market (see Table 2 for example quotations).

The findings in the dating phase indicate trust, commitment, and congruence at moderate to high levels. The partners expressed high expectations and potential of the collaboration. The project is part of a wider innovation community, in which many of the partners have collaborated in earlier projects and thus have knowledge of one another. This enabled high initial levels of trust, commitment, and congruence. Moreover, the partners had extended experiences of technology exchange through the previous collaboration projects. However, the new component of this collaboration was the extent to which it included the development of joint business offerings.

\section{Brainstorming phase}

In the brainstorming phase of the collaboration, the partners placed particular emphasis on technology exchange and progress. Regarding financial capital, the creation of a mutual business model was generally considered to be important for commitment. At the same time, some partners began to express concerns about the financial exchange and progress in the collaboration, indicating decreasing levels of trust. They reported difficulties in communicating the financial benefits of partnership and emphasized the lack of financial exchange. Although there was a generally neutral tone among the partners regarding how to finance and conduct business within the collaboration model, they avoided discussing details of who, where, and how. The partners began to express doubts about the business potential of the collaboration. Taken together, this shows low levels of trust, commitment, and congruence in terms of financial capital. 
Table 2 Discourse in the dating phase

\begin{tabular}{|c|c|}
\hline \multicolumn{2}{|c|}{ Exchange of capital-dating phase } \\
\hline \multirow[t]{3}{*}{$\begin{array}{l}\text { Financial } \\
\text { capital }\end{array}$} & $\begin{array}{l}\text { "I think anybody should be interested to pay for this kind of service."'... we can decide internally } \\
\text { how to price things, in that respect we are also dependent on the pricing of the testbed providers } \\
\text { themselves and they don't have a clue yet how to price... So maybe the first customers will be } \\
\text { guinea pigs and we might offer them a service for free just to figure out how things work... We } \\
\text { should have a business model and business plan.".... we want to become big. I don't see it right } \\
\text { now, but before that I would say first it should run, self-sustained for a couple of years..." }\end{array}$ \\
\hline & $\begin{array}{l}\text { "... we hope that we convince the industry, especially to commit a certain number of years to } \\
\text { financially contribute to this collaboration model." }\end{array}$ \\
\hline & $\begin{array}{l}\text { "...we will find a financing model once the first income comes into the collaboration model, in } \\
\text { terms of money flow ideally the providers would not have to pay anything." }\end{array}$ \\
\hline \multirow[t]{2}{*}{ Human capital } & $\begin{array}{l}\text { "On the project level, of course there are risks, related to the competencies of the people whether } \\
\text { companies send the right people or if, the level of engagement is low or so." }\end{array}$ \\
\hline & $\begin{array}{l}\text { "I have trust in the people who are doing the technology development." We have experience of } \\
\text { connecting testbeds around the world. We can make it work but this far it has never been easy." }\end{array}$ \\
\hline \multirow[t]{5}{*}{ Social capital } & $\begin{array}{l}\text { "I think there is a lot of trust needed to operate this collaboration model for the benefit of all } \\
\text { partners. This currently is really based on the social networks or the professional social networks } \\
\text { that exist from previous relationships, from previous projects and generally the engagement of all } \\
\text { partners in different forms of collaboration over the years. So this is how it currently works and } \\
\text { probably it will work if we succeed to create this collaboration model and operate it and, on a } \\
\text { sustainable basis." }\end{array}$ \\
\hline & $\begin{array}{l}\text { "...we have very good collaboration with project partners in the past and we still have that."."... } \\
\text { we know them and we have worked with them before."'We have developed those relationships } \\
\text { over a number of years." }\end{array}$ \\
\hline & $\begin{array}{l}\text { "...competition isn't an issue as it would be for other organizations. I think the businessmen in our } \\
\text { cluster would actually be very happy to work with a lot of the partners..." "This is a good project } \\
\text { from the idea that people meet and they know each other's companies, testbeds and R\&D." }\end{array}$ \\
\hline & $\begin{array}{l}\text { "I had close collaboration with the project management in the past and this is how we got into } \\
\text { this collaboration... we have participated with other partners in several projects before. I'm here for } \\
\text { collaborating in a specific technical area, it's much easier for me to do with somebody that I } \\
\text { know." }\end{array}$ \\
\hline & $\begin{array}{l}\text { "If the organizations changes and people change their positions inside the organizations, you have } \\
\text { to build trust over and over again, with different people. Sometimes in big companies if you loose } \\
\text { one contact it takes a year or two to find another who is in charge of that business area. That's } \\
\text { hard work." }\end{array}$ \\
\hline \multirow[t]{2}{*}{$\begin{array}{l}\text { Innovation } \\
\text { capital }\end{array}$} & $\begin{array}{l}\text { "Currently we have no major risks, the competition is certainly not a risk. All partners accept the } \\
\text { fact that it is pre-competitive collaboration and even if the collaboration model creates a business } \\
\text { case for some organization I think most of the organizations engaged, are convinced that they } \\
\text { create an entity, a facility that is of the long term benefit of the whole industry."'I would say that } \\
\text { technology risk is lower, knowing the other partners." }\end{array}$ \\
\hline & $\begin{array}{l}\text { "... you get access to others resources around Europe.".... if the customers can rely on and trust } \\
\text { the collaboration model it's useful, then they are going to use resources provided by the } \\
\text { collaboration model and then the business model will work. If people chose the collaboration } \\
\text { model they will pay and will help to maintain the collaboration model. If you can trust the } \\
\text { resources then maybe you will use it." }\end{array}$ \\
\hline
\end{tabular}

Human capital primarily involved engineers and only a few business people. We observed in the project meetings that neglecting the inclusion of business competence appeared to be a conscious and deliberate decision since the exchange of information on the design of business offerings could be avoided. Some partners signaled a need to involve business competence to attain progress in the collaboration model, indicating moderate levels of congruence. Trust and commitment that the partners provided the appropriate competence was low in terms of business competence and high for technology competence.

Social capital primarily revolving around technology exchange was viewed in a relatively positive way. The importance of closeness and trust among partners was emphasized, indicating a high level of trust. The partners particularly emphasized the value of 
collaboration and exchange in technology and focused on the progress of technology. However, the partners noted a varying degree of commitment among each other, where some partners worked daily with the innovation while others were less active, indicating a moderate level of commitment. Some expressed that the value of the collaboration was that it provided a way to keep their relations alive. Others noted that there might not be actual incentives for all partners to participate, indicating moderate levels of congruence.

The partners focused on innovation capital, viewing the collaboration as a platform for the potential exchange of ideas. They began to address business model issues, and the core topic was technology exchange. Trust issues were also raised regarding information leakage related to innovation capital, that is, concern as to whether the partners had each others' best interests at heart, indicating a moderate level of trust and congruence as partners had, to some extent, different views on the exchange of innovation capital. The partners who had direct contact in the collaboration expressed higher levels of trust, commitment, and congruence compared to those who did not have such contact. The commitment of the partners decreased slightly, and they began to discuss risks regarding the exchange of innovation capital, but they still emphasized the need for innovation capital exchange (see Table 3 for example quotations).

The findings in the brainstorming phase indicate a lack of collaboration regarding business exchange, and neglecting the inclusion of business competence appeared to be a conscious and deliberate decision. Trust, commitment, and congruence were predominantly expressed as facilitators for the technology exchange. The partners also expressed the importance of direct collaboration in the technology exchange, whereas it was more or less absent in the business exchange.

\section{Decision phase}

During the decision phase, the partners primarily exchanged innovation capital by focusing on technology development activities supported by financial, human, social, and innovation capital, and the collaboration generated a successful infrastructure technology platform. Nevertheless, the lack of exchange related to joint business exploitation resulted in project failure as no commercial or sustainable business platform was generated. The competitive situation became evident as opportunities to make money on the developed technology motivated solitary business exploitation, resulting in a low degree of business information exchange. Financial capital issues related to pricing became central, with discussions in meetings focused on "who will buy and who will get paid." It became evident through observations of meetings that the partners did not agree on how money should flow, raising doubts about market potential and showing low levels of trust, commitment, and congruence in terms of financial capital.

While the project staff had the technological competence needed to carry out the innovation, business competence was lacking. Thus, in regard to human capital, there were continued high levels of trust and commitment in technology competence but low levels of trust and commitment in business competence. The congruence in human capital was low as large company partners expressed a lack of joint business potential while other partners saw significant joint business potential. The commitment of the partners became a central issue with regard to social capital, and doubts were expressed 
Table 3 Discourse in the brainstorming phase

\begin{tabular}{|c|c|}
\hline \multicolumn{2}{|c|}{ Exchange of capital-brainstorming phase } \\
\hline \multirow[t]{3}{*}{$\begin{array}{l}\text { Financial } \\
\text { capital }\end{array}$} & $\begin{array}{l}\text { "The project is a high risk project. We've been fighting this battle for a while so, if the project } \\
\text { cannot get the critical mass of adoption of users and of providers in the beginning of the project } \\
\text { it will be hard for the project to continue or exist as a collaboration model... there needs to be an } \\
\text { economic incentive for partners."'There is quite little money nowadays in the high technology } \\
\text { based testing business. During this project we should be able to develop the tools to increase the } \\
\text { whole business ecosystem, and when there is something to share companies will more willing } \\
\text { join." }\end{array}$ \\
\hline & $\begin{array}{l}\text { "We need to clearly communicate the benefits to the industry, because we say the industry should } \\
\text { finance a large part of it. We are not there yet, we don't have clear communication." }\end{array}$ \\
\hline & $\begin{array}{l}\text { "The measure for the success of the collaboration model is at the end, if it succeeds to be } \\
\text { economically viable then this means that the collaboration model must be doing some right. If } \\
\text { this does not succeed in the long term, if partners start to pull out, then we did something } \\
\text { wrong." }\end{array}$ \\
\hline Human capital & $\begin{array}{l}\text { "...if it comes to the point of bringing this to the market you have to involve more people with } \\
\text { experience and marketing. Otherwise it's a problem you cannot ask people sitting in their labs } \\
\text { each day to come up with some clever marketing strategies; it's not just their job to think of so } \\
\text { that's why they don't expect it.". }\end{array}$ \\
\hline \multirow[t]{2}{*}{ Social capital } & $\begin{array}{l}\text { "We should have tight connections inside the project first, so we can show the use case and real } \\
\text { business case inside the project it's then easier to make it interesting for external partners."'The } \\
\text { collaboration model might be the center point to keep these contacts alive."'Some partners are } \\
\text { regularly in contact, not necessary daily but at least weekly, while some partners are silent and less } \\
\text { active."'... talk to them potential partners, face to face, know them, otherwise you cannot get } \\
\text { them to commit."'Trust that's the most important thing. You gain trust and after that everything } \\
\text { is easy."'Trust it's about playing golf with the right people and explaining to them why it's useful } \\
\text { to join the collaboration and useful is just commercial interests. If you cannot earn anything on } \\
\text { the platform it's not useful. It would be useful if we could understand the real motivation of the } \\
\text { partners." }\end{array}$ \\
\hline & $\begin{array}{l}\text { "From a technical or social point of view, it really needs to be a tightly integrated team where } \\
\text { there are actually incentives for all partners."'Organizations do not do business alone. People do } \\
\text { business, people have relationships, and trust. Trust is an important factor. But I'm quite sure that } \\
\text { building this kind of society around this testing business helps to know people and increases trust. } \\
\text { If people trust each other the organizations will more or less do the same." }\end{array}$ \\
\hline \multirow[t]{3}{*}{$\begin{array}{l}\text { Innovation } \\
\text { capital }\end{array}$} & $\begin{array}{l}\text { "We can bring in our ideas and we can at the same time see what the others have been thinking } \\
\text { of this same issue, this is an exchange of ideas. Exchange of resources is difficult, every partner } \\
\text { tries to utilize their own resources best possible way, and that's natural, it's acceptable."'We want } \\
\text { technological exchange... started to think about the business model, it's under development... } \\
\text { and nowadays we are only thinking about the technical problems... we are not thinking right } \\
\text { now on the business." }\end{array}$ \\
\hline & "There are of course technological risk, management also, the technology is a high risk." \\
\hline & $\begin{array}{l}\text { "Trust has many dimensions, I don't know if it's true that the system that will be developed will be } \\
\text { secure and natural, people will feel comfortable enough to use it. If companies feel that there may } \\
\text { be leakage of information to somebody else that will definitely significantly disable the } \\
\text { sustainability. Companies that are dependent on a very specific technology, like one patent, will be } \\
\text { very skeptical if they do not get the guarantees they want from the trust point of view or because } \\
\text { of industrial espionage and so on. But I assume that the technology is secure at a certain level } \\
\text { where many of these problems can be handled. I think that it should not create a problem." }\end{array}$ \\
\hline
\end{tabular}

as to whether the partners would commit to and sign contracts due to conflicting views on how to conduct business, that is low levels of congruence how to do business. Several partners were more interested in the collaboration as such than in the joint business offerings. Some even expressed that collaborating made their efforts worthwhile even though the end results of the collaboration might be poor. Important observations of meetings at the end of the collaboration project revealed that the social capital of business collaboration between partners consisted of low levels of trust and commitment among partners, which negatively influenced the development of the collaboration model. 
In discussions, the competitive situation became evident, where opportunities to make money on the developed technology motivated solitary rather than collaborative business exploitation. Innovation capital revolved around the complexity of the technology, where doubts about customers' needs for the service and divergent partner interests were raised, which negatively affected trust and commitment in innovation capital. Partners rationalized the lack of a good business outcome from the technology as a timing and sensitivity issue related to information and resources. General incentives for being part of the collaboration project were expressed by emphasizing visibility, the shorter time to market, and staying updated on emerging technologies. Rationalizations of the failure revolved around timing and market window problems (see Table 4 for example quotations).

At the point in time when the business model was meant to be launched, the tone of the partners changed, becoming increasingly skeptical and questioning. Partners who had intended to share sensitive business model information from their own organizations changed their minds and either kept quiet or did not participate in partner meetings when it became evident that other partners had no intention of sharing or the implications of making use of the information became apparent, showing overall low levels of trust, commitment, and congruence.

\section{Social facilitators and a social accelerator for exchange}

The case illustrates that the extensive social exchange of information in technology development does not automatically result in successful business information exchange and exploitation. The initial high levels of trust, commitment, and congruence in financial, human, social, and innovation capital kick-started the technology exchange in the dating phase, as summarized in Table 5. The trust revolved mainly around confidence in the partners having the appropriate competence for success. Commitment was built on the mutual benefits that would be realized if the collaboration project was successful, and congruence was generally high due to the negotiated collaboration agreement.

In the brainstorming phase, trust was expanded to include the question of whether partners had each others' best interests at heart, for instance, with regard to information leakage. This indicates that trust may have several facets and may change during the course of a collaboration project. Commitment and congruence were also affected during this phase, where some partners were fully committed while others were more or less inactive or even absent. Direct contact in a collaboration can be viewed as an accelerator for exchange as it is a way to strengthen trust, commitment, and congruence among partners. Congruence appears to be less important when trust and commitment are low.

The findings in the decision phase indicate that while a lack of trust, commitment, and congruence manifested in the collaboration regarding business exchange, these facilitators still existed between the partners with regard to technology exchange. The partners also expressed direct collaboration in the technology exchange, although the neglect of-or refusal to-participate in business exchange severely hindered the progress of implementing innovation capital in a collaborative business model. Although the technology was successfully developed, the failure to negotiate the business terms caused the project to fail to achieve its overall objectives. Low levels of trust, commitment, and congruence led the collaborating partners to neglect or even refuse to 
Table 4 Discourse in the decision phase

\begin{tabular}{|c|c|}
\hline \multicolumn{2}{|c|}{ Exchange of capital_-decision phase } \\
\hline \multirow[t]{2}{*}{$\begin{array}{l}\text { Financial } \\
\text { capital }\end{array}$} & $\begin{array}{l}\text { "But what could be the commercial interest of somebody to join, there could be some kind of a } \\
\text { clash of interests for some of the partners. On one hand they already have their running } \\
\text { operations so obviously they are also interesting in selling their own stuff. The question is now, } \\
\text { how are actually the compensations distributed between the collaboration model and partners. I } \\
\text { think this will be necessary to discuss because otherwise partners could reject to join the } \\
\text { collaboration model because it's contradicting to their business model."'Nobody will invest money } \\
\text { unless they also get some money.".... If it's useful they will use it because they gain money and if } \\
\text { the opportunity fits in their plans they will not go out of their way to participate in the } \\
\text { collaboration model."If you don't bill them at least ask them how much they would be willing to } \\
\text { pay for the functionality." }\end{array}$ \\
\hline & $\begin{array}{l}\text { "This is not a fast growing business area, and I don't see any venture capitalist in the world that } \\
\text { would invest in the slow growing business opportunities." }\end{array}$ \\
\hline \multirow[t]{2}{*}{ Human capital } & $\begin{array}{l}\text { "..the most important people in the company are sales persons, because they bring in the revenue } \\
\text { and they know what the customer wants. You should have people from sales, trying to push your } \\
\text { concepts... These are the people that should be involved in technology projects but that never } \\
\text { happen." }\end{array}$ \\
\hline & $\begin{array}{l}\text { "In technology there are very important partners within the project, who are on top of the latest } \\
\text { technologies so keeping in contact with these partners is very important. However, for the big } \\
\text { companies it is not that important, because they don't see a business opportunity..." }\end{array}$ \\
\hline \multirow[t]{3}{*}{ Social capital } & $\begin{array}{l}\text { "I think collaborating in this project is useful. Even though it fails." "We are still on page one and I } \\
\text { had expected a lot more from this project and I have really made an effort. People are not } \\
\text { interested in talking and doing business."'... now we have to put into the discussion of } \\
\text { committing partners and they have to see something coming out of this."'Some companies are } \\
\text { afraid of competition through the collaboration." "Importance of networking rather than the } \\
\text { importance of the actual outcomes is our incentive for working with the collaboration } \\
\text { model."'Good luck in getting people to sign the agreement."... if we send this contract at the end } \\
\text { of the project, I'm afraid that no one will sign it. I think that it's the similar behavior with all the } \\
\text { major players, the bigger the partner is the less they will listen to the small players." "Acceptable } \\
\text { contracts is the most challenging thing, we have descriptions of contracts, how to connect this } \\
\text { best together but I haven't seen anybody signing those, not yet." }\end{array}$ \\
\hline & $\begin{array}{l}\text { "The success, like all projects we've been in the past, have all had a successful process but } \\
\text { doubtable results." }\end{array}$ \\
\hline & $\begin{array}{l}\text { "I think trust is a major issue in business. It's building up and securing and maintaining that trust } \\
\text { is always difficult. Very easily lost." }\end{array}$ \\
\hline \multirow[t]{3}{*}{$\begin{array}{l}\text { Innovation } \\
\text { capital }\end{array}$} & $\begin{array}{l}\text { "The project has focused on new technologies but not real business. Because real business } \\
\text { contains very sensitive information. It's easier to share resources but in real business you cannot } \\
\text { share information." }\end{array}$ \\
\hline & $\begin{array}{l}\text { "... they some large partners are not going to open their testbeds, so it's important that the } \\
\text { partners are not competitors." }\end{array}$ \\
\hline & $\begin{array}{l}\text { "The collaboration is a place for you see interesting ideas and you can take them to your } \\
\text { organization. For example, now in my company working in that area we can reinforce this } \\
\text { idea." "Sometimes ideas are too early for the time and if you do it ten years later with better } \\
\text { technology then it will be a better success, you never know."' think this whole business problem is } \\
\text { that nobody understands what it is." }\end{array}$ \\
\hline
\end{tabular}

engage in business exchange and instead resort to alternative forms of exchange (e.g., hindering business information exchange or making it less productive, pretending to be interested in exchange, and making positive business effects less likely to occur). It is evident from the three phases that trust may be viewed as a particularly important facilitator as it is the foundation for commitment, and without trust and commitment, congruence is not particularly interesting for partners.

\section{Conceptualizing three social facilitators and a social accelerator}

Based on the findings above, we further conceptualize the social facilitators below. Trust consists of the belief that partners will have and provide the appropriate 
Table 5 Summary of social facilitators in collaboration phases

\begin{tabular}{|c|c|c|c|c|c|c|c|c|c|}
\hline & \multicolumn{3}{|c|}{ Dating phase } & \multicolumn{3}{|c|}{ Brainstorming phase } & \multicolumn{3}{|c|}{$\underline{\text { Decision phase }}$} \\
\hline & Trust & Commitment & Congruence & Trust & Commitment & Congruence & Trust & Commitment & Congruence \\
\hline Financial capital & Moderate & Moderate & High & Low & Low & Low & Low & Low & Low \\
\hline Human capital & High & Moderate & Moderate & High/low & High/low & Moderate & High/low & High/low & Low \\
\hline Social capital & High & High & High & High & Moderate & Moderate & Moderate & Moderate & Moderate \\
\hline Innovation capital & High & High & High & Moderate & High & Moderate & Moderate & Low & Low \\
\hline
\end{tabular}


resources (including competence) for the collaboration project to succeed, and that partners will have each others' best interests at heart in actions taken during the collaboration project. Trust thus involves the willingness of a partner to be vulnerable to another partner's actions based on the anticipation that the other partner will act in a way that is beneficial to the trustor.

Commitment is conceptualized as the willingness of partners to invest resources including competences into the collaboration project because of the importance of strengthening and maintaining the ongoing relationship with exchange partners. High commitment necessitates positive regard for the other partners. Commitment is also related to the trade-off between termination or switching costs associated with leaving the relationship and the benefits of remaining in the collaboration. Congruence is conceptualized as the agreement among collaboration partners regarding a shared exchange process and outcome view. Trust, commitment, and congruence are thus highly interrelated.

The accelerator for exchange is viewed as the direct contacts in the collaboration, which are a means of strengthening trust, commitment, and congruence among collaborating partners. In our study, direct contacts based on negotiated established structures for exchange were present in the technology exchange between the collaboration partners. Direct contact was available in the technology exchange because of the partners' previous collaboration in similar projects. In direct contact situations, partners build trust, commitment, and congruence through advisory practices (i.e., asking for others' expertise on various matters in solving project progress issues). Consequently, they create bounds and "flatter" each other, which accelerate the social facilitators for exchange. The project was staged with recurring forums for direct contact and advisory practices related to technology. In contrast, business forums occurred on only three occasions and on a general level, without the appropriate competences present. Participating engineers discussed the business model, but they lacked the competence to ask for or provide advice, which hindered building trust, commitment, and congruence in the business exchange. The business exchange was built on indirect contacts since the personnel involved lacked business competence and each partner was either only indirectly engaged or non-existing. Further, the business exchange was intended to be reciprocally developed and negotiated at the end of the project.

The three social facilitators relate to the general principle of reciprocity in social exchange theory (Blau 1964; Emerson, 1976). High levels of trust make partners willing to take risks and contribute directly to collaborations as they anticipate reciprocity in their partners' contributions. In contrast, low levels of trust cause partners to become hesitant or unwilling to take any risks by contributing since they are not convinced that their partners will contribute reciprocally. High commitment stems from the willingness of the partners to invest resources to strengthen the relationship. This is evident through repeated reciprocity and facilitates exchange as it leads to loyalty among partners. With low commitment levels, partners will avoid investing in the relationship, and thus reciprocity will not occur. High congruence stems from the collaborating partners agreeing on the exchange and the outcome of the collaboration, which makes expected reciprocity actions clear to partners. Low congruence means that partners do not agree or coincide on the exchange or the outcome of the collaboration, which hinders reciprocity actions. 


\section{Discussion and Conclusions}

This article shows the role of social facilitators in project success and failure and provides implications of how such social facilitators may be accelerated by direct contact. Trust, commitment, and congruence are three interrelated facilitators, which stimulate a relational bond between the collaborating partners that facilitates productive collaborations. However, if the facilitators are weak, the collaboration may be in jeopardy and risks failure. Our findings imply that if the partners that are selected to be involved in the collaboration have appropriate competences, significant opportunities will be provided for direct contact. A lack of competence inhibits the ability to exchange and prevents social facilitators from working efficiently in the exchange, whereas the presence of competence enables exchange, which the social facilitators enable and the direct contacts accelerate.

This study is anchored in Blau's (1964) work regarding the social exchange process and the collaboration in innovation that follows from organizations' desire for innovation competitiveness and growth. However, while social exchange theory offers little guidance in understanding the microfoundations of why some collaborations in innovation lead to business offerings that prosper in a marketplace while others fail, the findings of this study support the notion that social facilitators and a social accelerator in the process and outcomes of collaborations in innovation make it possible to manage the collaboration outcomes. This study shows the importance of the mechanisms, direct contacts for accelerating social facilitators for exchange, and collaboration outcomes. Although social facilitators are dealt with in collaboration agreement contracts in line with the negotiation principle, the reciprocity principle appears to be more powerful than the negation principle in successful exchange and collaboration outcomes (Das and Teng 1998; Molm et al. 1999; Molm et al. 2000). As such, this study provides implications regarding conceptual development to the literature on collaboration in innovation.

The three collaboration project phases and four types of capital identified reflect the way in which social exchange influences collaboration outcomes. The conceptualization of the types of capital extends the previous research on innovation collaboration (e.g., Caloghirou et al. 2003; Hagedoorn et al. 2000; Vonortas 1997; Laperche and Liu, 2013; Spivack 2013). The collaborative partners focused on building long-term relations in technology development while they placed less emphasis on generating business exploitation, which may be understood by the three social facilitators and the social accelerator. "Poor" relationships among collaborative partners have been identified in prior studies as one reason for collaboration failure (Timmons 1994). By understanding how social facilitators drive the exchange in relationships, dysfunctional collaboration processes may be redirected and positive interactions enhanced. Trust, commitment, and congruence are the three types of social facilitators that cultivate exchange, and our findings show how a lack of social facilitators leads to failure in achieving commercialization, sustainability, and success in technology development (Mouritsen et al. 2001). These social facilitators appear to be central for understanding collaboration project failure. Low levels of trust, commitment, and congruence impede social exchange in business exploitation and consequently result in negative outcomes since no common business offering is generated. In contrast, these facilitators enable social exchange in technology development and are accelerated by direct contacts, leading to 
significant progress (Blau 1964; Holmes 1981; Kingshott 2006; Johansson 2007; Blomkvist et al. 2015). Prior studies have also found that trust in collaborative relationships is crucial for exchange to result in positive effects such as technology and business exploitation (Lado et al. 2008: Das and Teng 1998). Barns and colleagues (2006) stress the importance of social relationships and trust for successful collaborative projects. In addition, prior studies have shown commitment to be useful for predicting collaborative progress (Meyer 1997; Mohr and Speakman 1994). Studies have also shown that commitment is more important for the implementation of business innovation than for the initiation of technology innovation. Congruence has also been shown to be critical for technological innovations, with a cultural foundation of congruence among partners enhancing the potential for exchange information (Gudmundson et al. 2003; Jones et al. 1997). This study adds to the insights of previous studies with a new conceptualization of social exchange that details the microfoundations of social exchange.

The partners' unwillingness to exchange business information impeded the overall project outcome. There is a risk of a lock-in situation in innovation projects, where collaborations repeat positive progress in technology development but fail to exploit business opportunities. Such lock-in situations may place the organizations' competitive advantages at risk, leading to a paradox. Partners contributing essential business information to the innovative collaboration may severely weaken the competitive advantages of their own organizations. In contrast, an organization that does not contribute such information to the collaboration may sustain their own competitive advantages while simultaneously impeding the progress of the innovation outcomes, thereby potentially weakening their future competitive advantages. This drives collaboration exchanges in opposite directions and highlights a collaboration exchange paradox. Taken together, this helps to explain challenges in innovation collaboration by showing that low levels of trust, commitment, and congruence improve understanding of the consequences of social facilitators in social exchange and their significance to the outcomes of innovation collaborations as well as the impact of direct contacts on the accelerating social facilitators for exchange.

Practically, this study highlights the importance of building and operating structures for exchange aligned with the scope of the collaboration project. Accordingly, the collaboration model needs to address social exchange of all types of capital central to the collaboration objectives. In addition, collaboration models need to enable trust, commitment, and congruence as well as direct collaborative contacts in the exchange of all types of capital. Such collaboration models may enhance the outcomes of collaboration projects and simultaneously lower the potential of failure.

\section{Limitations and future research}

As with all studies, our work has limitations. We encourage future studies to use larger samples of social exchange processes to test the current findings. Such studies will help assess the reliability and validity of the presented results and further extend our knowledge of collaborative innovation processes in social exchange frameworks. We argue for more explorative studies that include social exchange theory concerning the circumstances of collaboration in innovation. While the present study was conducted with a qualitative research setup, we encourage future researchers to expand on this topic. 
Social exchange processes are not static; they are adaptable social systems and typically evolve over time, which is why a qualitative approach may reveal valuable insights. Therefore, future studies are encouraged to consider further testing and development through longitudinal studies over longer time horizons.

\section{Appendix 1}

\section{Fundamental collaboration principles}

In particular, the following principles are adopted as fundamental for an efficient testbed collaboration that provides added value to European research on future networks and services.

\section{Openness}

Collaboration implies openness at all levels, including provision, implementation, and use. Concerning provision, the collaboration must be open for any testbed of the European testbed ecosystem. There are many related issues that make the implementation of openness a challenge. These include intellectual property rights (IPR), how to exchange results and what may be shared, the standardization of interfaces, common procedures, and usage policies. The implementation could be done through open source tools and open hardware design details, which would enable easy replication, interfacing, and inter-operation among various testbed components, and consequently, would increase the overall effectiveness and impact of the collaboration. Use will be open to any relevant European and worldwide initiative under fair access terms and in accordance with IPR-related rules adopted by testbed providers and users.

\section{Excellence}

The collaboration principle aims for "best of breed" and must ensure excellence of the capabilities of the collaboration from various aspects. These aspects include, among others, (1) degree of innovation, (2) measurable quality or compliance to essential standards, (3) diversity, and (4) scale or geographic coverage. Criteria must be developed that allow for a transparent evaluation of excellence and the reclassification of a testbed as a commodity-and thus its removal from the collaboration.

\section{Efficient management}

Managing collaboration testbeds is complex but necessary for achieving scale, diversity, cost-efficiency, and to improve the sustainability and quality of the individual testbeds and the collaboration as a whole. The traditional network management objectives also apply to the management of collaborated testbeds. In order to provide efficient and cost-effective management of the collaborated testbeds, a dedicated entity responsible for (project) operation, including handling of all organizational issues, might be established. The operation and management of each of the testing resources assigned to the collaboration remain the responsibility of its original owner, who determines the extent/level of operating and managing the resource through the collaboration environment. 


\section{Governance}

Interconnecting different testbeds belonging to different administrative domains means granting access to remote resources that are owned by different stakeholders. This has the consequence that a legal framework must be in place that governs these relations and must include the following: handling of IPR, a definition of confidentiality and trust, a process for resolving conflicts, and handling of the misuse of rights or neglected obligations. In order to lay the foundation for establishing a long-term sustainable testbed collaboration, a legal entity might prove necessary. This legal entity must manage the different relations, possibly manifested as contracts, between the stakeholders that interconnect their resources in the scope of the collaboration.

Competing interests

The authors declare that they have no competing interests.

\section{Authors' contributions}

They were equally and actively involved in the design, data collection, analysis work, literature review, and writing of the article.

\section{Biographical notes}

Malin Malmström is an associate professor of accounting and control at the Luleå University of Technology. Much of her research revolves around behavioral, social, and organizational aspects related to strategic actions and performance consequences. Her research interests relate to cognitive foundations, competences and experiences in entrepreneurship, and innovation.

Jeaneth Johansson is an associate professor of accounting and control at the Luleå University of Technology. Her research interests are in the field of financial decision-making, financial accounting, entrepreneurship, and innovation.

Received: 8 October 2015 Accepted: 8 January 2016

Published online: 21 January 2016

\section{References}

Amit, R., \& Schoemaker, P. J. H. (1993). Strategic assets and organizational rents. Strategic Management Journal, 14(1), $33-46$. Anderson, E. (1990). Two firms, one frontier: on assessing joint venture performance. Sloan Management Review, 31(2), 19-30. Barnes, T. A., Pashby, I. R., \& Gibbons, A. M. (2006). Managing collaborative R\&D projects development of a practical management tool. International Journal of Project Management, 24(5), 395-404.

Blau, P. M. (1964). Exchange and power in social life. New York: John Wiley.

Blomkvist, M., Johansson, J., \& Malmström, M. (2015). Accounting Knowledge in Innovative Firms: Direct Contacts with Auditors for Strategic Actions. Artikeln har presenterats vid American Accounting Association Annual meeting and conference on teaching and learning in Accounting, Chicago, USA.

Brass, D. J., Galaskiewicz, J., Greve, H. R., \& Tsai, W. (2004). Taking stock of networks and organizations: a multilevel perspective. Academy of Management Journal, 47, 795-817.

Caloghirou, Y., loannides, S., \& Vonortas, N. S. (2003). Research joint ventures: a critical survey of theoretical and empirical literature. Journal of Economic Surveys, 17(4), 541-570.

Chesbrough, H. (2010). Business model innovation: opportunities and barriers. Long Range Planning, 43(2), $354-363$.

Chesbrough, H., \& Rosenbloom, R. S. (2002). The role of the business model in capturing value from innovation: evidence from Xerox Corporation's technology spin-off companies. Industrial and Corporate Change, 11(3), 529-555.

Chronéer, D., Johansson, J., \& Malmström, M. (2015). Business Model Management Typologies: Cognitive Mapping of Business Model Landscapes. International Journal of Business and Management, 10(3), 67-80.

Cropanzano R., \& Mitchell, M. S. (2005). Social exchange theory: an interdisciplinary review. Journal of Management, $31(6), 874-900$.

Das, T. K., \& Teng, B.-S. (1998). Between trust and control: developing confidence in partner cooperation in alliances. Academy of Management Review, 3(July), 491-512.

Emerson, R. M. (1976). Social exchange theory. Annual review of sociology, 335-362.

Emden, Z., Calatone, R. J., \& Droge, C. (2006). Collaborating for new product development: selecting the partner with maximum potential to create value. Journal of Product Innovation Management, 23, 330-341.

Eisenhardt, K. M. (1989). Building theories from case study research. Academy of Management Review, 14(4), 532-50.

Gouldner, A. W. (1960). The norm of reciprocity: a preliminary statement. American Sociological Review, 25, 161-178.

Goerzen, A. (2007). Alliance networks and firm performance: the impact of repeated partnerships. Strategic Management Journal, 28(1), 487-509.

Gudmundson, D., Tower, C. B., \& Hartman, E. A. (2003). Innovation in small businesses: culture and ownership structure do matter. Journal of Developmental Entrepreneurship, 8(1), 1-17.

Hagedoorn, J., Link, A. N., \& Vonortas, N. S. (2000). Research partnerships. Research Policy, 29(4-5), 567-586.

Holmes, J. G. (1981). The exchange process in close relationships: microbehavior and macromotives. In M. J. Learner \& S. C. Lerner (Eds.), The justice motive in social behavior (pp. 261-284). New York: Plenum.

Homans, G. C. (1958). Social behavior as exchange. American Journal of Sociology, 63, 579-606.

Johansson, J., \& Malmström, M. (2013). The business model transparency paradox in innovative growth ventures: tradeoffs between competitive advantages and agency costs. Entrepreneurship Research Journal, 3(2), 238-263. 
Johansson, J. (2007). Sell-side analysts' creation of value: key roles and relational capital. Journal of Human Resource Costing \& Accounting, 11(1), 30-52.

Jones, C., Hesterly, W. S., \& Borgatti, S. P. (1997). A general theory of network governance: exchange conditions and social mechanisms. Academy of Management Review, 22(4), 911-945.

Kingshott, R. P. J. (2006). The impact of psychological contracts upon trust and commitment within supplier buyer relationships: a social exchange view. Industrial Marketing Management, 35(6), 724-739.

Knudsen, M. P. (2007). The relative importance of interfirm relationships and knowledge transfer for new product development success. Journal of Product Innovation Management, 24, 117-138.

Lado, A. A., Dant, R. R., \& Tekleab, A. G. (2008). Trust-opportunism paradox, relationalism, and performance in interfirm relationships: evidence from the retail industry. Strategic Management Journal, 29(4), 401-423.

Laperche, B., \& Liu, Z. (2013). SMEs and knowledge-capital formation in innovation networks: a review of literature. Journal of Innovation and Entrepreneurship, 2, 21. http://www.innovation-entrepreneurship.com/content/2/1/21.

Madill, J. J., Haines, G. H., Jr., \& Riding, A. L. (2007). Managing customer relationships: account manager turnover and effective account management. Industrial Marketing Management, 36, 241-248.

Malmström, M., Johansson, J., \& Wincent, J. (2015). Cognitive Constructions of Low-Profit and High-Profit Business Models: A Repertory Grid Study of Serial Entrepreneurs. Entrepreneurship: Theory and Practice.

Malmström, M. (2014). Typologies of bootstrap financing behavior in small ventures. Venture Capital - An International Journal of Entrepreneurial Finance, 16 (1), 27-50.

Malmström, M., Wincent, J., \& Johansson, J. (2013). Managing competence acquisition and financial performance: An empirical study of how small firms use competence acquisition strategies. Journal of Engineering and Technology Management, 30(4), 327-349.

Malmström, M. \& Wincent, J. (2012). Modeling Competence Acquisition in Small Firms. International Journal of Entrepreneurship and Innovation Management. 15, 1/2, 131-158.

Meyer, J. P. (1997). Organizational commitment. In C. L. Cooper \& I. T. Robertson (Eds.), International review of industrial and organizational psychology (pp. 175-228). New York: John Wiley.

Miles, G., Preece, S. B., \& Baetz, M. C. (1999). Dangers of dependence: the impact of strategic alliance use by small technology-based firms. Journal of Small Business Management, 37, 2.

Miles, M. B., \& Huberman, M. A. (1994). An expanded sourcebook: qualitative data analyses (2nd ed.). Thousand Oaks: Sage Publications.

Molm, L. D., Peterson, G., \& Takahashi, N. (1999). Power in negotiated and reciprocal exchange. American Sociological Review, 64, 876-890.

Molm, L. D., Takahashi, N., \& Peterson, G. (2000). Risk and trust in social exchange: an experimental test of a classical proposition. American Journal of Sociology, 105, 1396-1427.

Mohr, J., \& Speakman, R. (1994). Characteristics of partnership success: partnership attributes, communication behaviour, and conflict resolution techniques. Strategic Management Journal, 15, 135-152.

Mouritsen, J., Larsena, H. T., \& Bukhb, P. N. D. (2001). Intellectual capital and the 'capable firm': narrating, visualising and numbering for managing knowledge. Accounting, Organizations and Society, 26, 735-762.

Nieto, M. J., \& Santamaría, L. (2007). The importance of diverse collaborative networks for the novelty of product innovation. Technovation, 27(6), 367-377.

NVivo software, QSR International (http://www.qsrinternational.com/product) Accessed 25 Nov 2015

Osterwalder, A., \& Pigneur, Y. (2004). An ontology for e-business models. In W. Currie (Ed.), Value creation from ebusiness models. Oxford: Butterworth-Heinermann.

Rakhmatullin, R., \& Brennan, L. (2014). Facilitating innovation in European research area through pre-competitive EU-funded COST actions. Journal of Innovation and Entrepreneurship, 3, 6. http://www.innovation-entrepreneurship.com/content/3/1/6.

Rigby, J., \& Edler, J. (2005). Peering inside research networks: some observations on the effect of the intensity of collaboration on the variability of research quality. Research Policy, 34(6), 784-794.

Spivack, R. N. (2013). Small business participation in the advanced technology program research alliances. Journal of Innovation and Entrepreneurship, 2, 19. http://www.innovation-entrepreneurship.com/content/2/1/19.

Strauss, A., \& Corbin, J. (1990). Basics of qualitative research: grounded theory procedures and techniques. Newbury Park, CA: Sage Publications, Inc

Timmons, J. A. (1994). New venture creation; entrepreneurship for the 21st century. Sydney: Irwin.

Vonortas, N. S. (1997). Cooperation in research and development. Boston; Dordrecht: Kluwer Academic Publishers.

Yin, R. (2003). Case study research. Beverly Hills, CA: Sage Publications.

\section{Submit your manuscript to a SpringerOpen ${ }^{\circ}$ journal and benefit from:}

- Convenient online submission

- Rigorous peer review

- Immediate publication on acceptance

- Open access: articles freely available online

- High visibility within the field

- Retaining the copyright to your article

Submit your next manuscript at $\downarrow$ springeropen.com 